\title{
COMMUNITIES DEFEAT TERRORISM: POST-9/11 COMMUNITY ENGAGEMENT STRATEGIES
}

\author{
Rohan Gunaratna ${ }^{1}$ \\ Institute of Defence and Strategic Studies, Nanyang Technological University
}

\begin{abstract}
:
Upstream community engagement and downstream rehabilitation are novel strategies essential to fight the contemporary wave of terrorism. In the first decade following $9 / 11$, Western counter terrorism strategies failed adequately to recognize the importance of engaging the communities that produce terrorists and supporters. The West and the rest of the world are unlikely to win the fight against Muslim terrorism without winning over the Muslim communities. The global counter terrorism policy and strategy is Western-led. As such, both practitioners and scholars from the US, Europe and Australia should invest time and energy identifying and sharing best practices in community engagement and rehabilitation. A few countries in Asia and the Middle East have built well structured and ad-hoc programs that can be shared with the rest of the world. Both community engagement and rehabilitation requires an understanding of the affected societies and communities at risk of producing terrorists and extremists. It requires the governance and community structures to partner in creating new platforms for community engagement and terrorist disengagement and deradicalization. This new frontier in fighting terrorism requires visionary leadership, sustained resources, and partnerships between the political structures, the community elite and the private sector. To influence the human terrain, the range of stakeholders includes government and community working with the media, religious establishment and educational authorities.
\end{abstract}

Keywords: Community Engagement, Rehabilitation, Counter-terrorism.

\section{Resumen:}

La inclusión de las comunidades locales y la rehabilitación son estrategias novedosas para luchar con la actual ola de terrorismo. En la primera década tras el 11-S, las estrategias contra-terroristas occidentales no lograron reconocer la importancia de la inclusión de las comunidades locales que generan terrorismo y apoyo a éste. Occidente y el resto del mundo difícilmente vencerán la lucha contra el terrorismo musulmán sin ganarse el apoyo de las comunidades musulmanas. Las politicas y estrategias globales de contra-terrorismo tienen una marcada impronta occidental. Tanto los decisores como los expertos de los EEUU, Europa y Australia deberían invertir tiempo y recursos para identificar y compartir las mejores técnicas de apoyo a nivel comuitario y de rehabilitación. Ambas estrategias requieren una comprensión de las sociedades afectadas y de las comunidades con riesgo de albergar el fenómeno del terrorismo y el extremismo. Las estructuras de gobernanza comunitaria tienen que erigirse en socios para la creación nuevas plataformas para la inclusión de las comunidades con el fin de rehabilitar a terroristas y promover la des-radicalización. Esta nueva frontera en la lucha contra el terrorismo requiere un liderazgo visionario, recursos sostenidos y una asociación entre las estructuras políticas, la élite de las comunidades y el sector privado. Para influir el terreno humano, hay que vincular a los gobiernos y a las comunidades en cooperación con los MM.CC., las autoridades religiosas y las autoridades educativas.

Palabras clave: Inclusión comunitaria, rehabilitación y contra-terrorismo.

Copyright (C) UNISCI, 2011.

Las opiniones expresadas en estos artículos son propias de sus autores, y no reflejan necesariamente la opinión de UNISCI. The views expressed in these articles are those of the authors, and do not necessarily reflect the views of UNISCI.

\footnotetext{
${ }^{1}$ Rohan Gunaratna is Director of the International Center for Political Violence and Terrorism Research, Nanyang Technological University (Singapore). 


\section{Introduction}

Terrorism by groups and homegrown cells did not plateau after 9/11. ${ }^{2}$ A review of the terrorist threat after $9 / 11$ demonstrates that the global threat of terrorism escalated after the US over-reacted to the threat. The US invasion and occupation of Iraq, driven by flawed understanding of the threat and faulty intelligence, was a major turning point in the loss of Muslim public support to fight terrorism. ${ }^{3}$ The resultant global Muslim suffering, anger and resentment were exploited by terrorist and extremist groups to generate support for the contemporary wave of extremism and terrorism.

Global counter terrorism policies, strategies and procedures are largely shaped by the West. Although over $95 \%$ of terrorism originates in the global south, the US, Europe and Australia play a significant role in building counter terrorism capacities in the south to fight terrorism. As the Western centric counter terrorism strategy did not focus on the public, the extremist ideologies and narratives driving the terrorist threat continue to grow. As government and terrorists compete for a common pool of community support, it is essential for governments to involve people to counter extremism and build social resilience.

Ten years after $9 / 11$, it is clear that without winning over the communities at risk, terrorism will continue and may even escalate. The communities targeted by the terrorists for recruitment and support needs to be engaged by government committed to reducing the threat. Without engaging the community producing the terrorists and supporters, the threat will persist and even grow. To defeat terrorism and its antecedent extremism, community engagement is a global imperative in the $21^{\text {st }}$ century.

\section{The Context}

In order to forge a common understanding, future stability and enduring peace, rather than government deciding and informing the community, building a collaborative relationship between government and community is essential. Rather than consultation and involvement, engagement and partnership within diverse communities and between governments and communities is paramount. To establish and sustain an engaged relationship with the community, government engagement should be not only with formal but informal representatives of the community providing community views.

Government must understand the local community (its nature, population, socioeconomic characteristics, history, culture and interests), engage in dialogue, and ensure effective participation and informed decision-making in planning process to address issues and bring about change. ${ }^{6}$ To reach out to a cross section of the community, government must identify and build relationships with well-established fora, networks of groups and

\footnotetext{
${ }^{2}$ Global Pathfinder 2, Database of the International Centre for Political Violence and Terrorism Research, Singapore.

${ }^{3}$ Mazzetti, Mark: "Spy Agencies Say Iraq War Worsens Terrorism Threat", New York Times, 24 September 2006 and http://www.systemicpeace.org.

4 Country Reports on Terrorism and prior to 2004, the Patterns of Global Terrorism produced by the US Department of State demonstrates this trend, at http://www.state.gov/s/ct/rls/crt/132196.htm.

5 Johnson, Robert: "America Has Failed To Reduce The Terrorism Threat Level Around The World Since 9/11”, Business Insider, 09 September 2011.

6 Hashagen, Stuart: "Models of Community Engagement", Scottish Community Development Centre (May 2002).
} 
individuals. Rather than a one way relationship, it should be both ways, and the interaction should be monitored, evaluated, and reviewed. These developmental partnerships, when resourced and financially supported, form the basis for a strong society and effective government. In addition to participation, the private sector can play a vital role. In case the government lacks resources, the private sector can step in and assist to build the community engagement initiatives.

\section{Rationale}

With the spread of extremist ideology and terrorist methodology through the internet and other platforms of communication, community engagement and terrorist rehabilitation has emerged as a vital pillar in counter terrorism. The four pillars of counter terrorism are:

(1) counter terrorism intelligence

(2) counter terrorism operations

(3) counter terrorism investigations

(4) community engagement and terrorist rehabilitation ${ }^{7}$

As opposed to traditional counter terrorism, it is critical to explore a population centric counter terrorism strategy. In such a strategy, governments must take into consideration the individual, the family, the community, and society seeking to win them over. By preventing extremism, the antecedents of terrorism, rather than reacting, government has much more to gain. By problem solving, engaging and building partnerships with the community, law enforcement and intelligence agencies can share the responsibility for fighting terrorism with the community. ${ }^{8}$

The community is the most critical resource base of the terrorist organization. ${ }^{9}$ To prevent the exploitation of the community as a resource base for the terrorists, government needs to create platforms and strategies to identify and engage vulnerable segments of the community. As opposed to law enforcement, community engagement is a community centered approach by stakeholders and partners to preserve protect and advance their collective interests and vision including harmonious living. A collective vision that benefits both communities, government and other partners can be achieved by raising awareness of each other's' interests particularly concerns.

\footnotetext{
7 It is debatable if terrorist rehabilitation should be categorized as a separate pillar. For the successful reintegration of rehabilitated terrorists back to society, community engagement is a must. If the community is not willing to accept those rehabilitated, the beneficiaries of rehabilitation will still remain in the margins of society susceptible to terrorist re-radicalization.

${ }^{8}$ Drawing from the International Conference on Community Engagement (ICCE): Countering Extremism and Building Social Resilience in Singapore in September 2011, this paper will focus on community engagement.

${ }^{9}$ Recommendation to The Way Forward panel by Malkanthi Hettiarachchi, delegate, International Conference on Community Engagement (ICCE), 22 September 2011.
} 


\section{Background}

With the advent of the Internet in the early 1990s, the capacity and capability of terrorist and extremist groups to politicize, radicalize and mobilize vulnerable segments of communities have increased exponentially. In the absence of a counter narrative, both territorial and migrant communities are increasingly vulnerable to the terrorist message. When members of the community are exposed to the terrorist message, it spreads like a virus enabling the terrorists to recruit them as sympathizers, supporters and members. As long as the terrorists operating under the cover of human rights, humanitarian, social, cultural, political, and community organizations are able to reach out to the community, terrorism and support for terrorism will emerge from communities. Although law enforcement and intelligence services can assist, eventually it is communities that can defeat terrorism. There must be greater understanding among community leaders that terrorism and extremism will harm and eventually damage their community gravely.

However, community leaders and elite themselves may not act by themselves to immunize their communities from the terrorist message promoting disharmony. As such, it is paramount for government leaders to hold hands with community leaders in raising the awareness of the community to this insidious threat of subversion and attack. Quite often community elite understand but government leaders do not understand either the importance of or they lack the will to invest in community engagement. Government leaders working in partnership with community elite must realize the paramount importance of protecting the community from such harm. The aim of the government working together with community and private sector partners should be to protect the community from harm.

Harm can come from ideological extremism taking root, manifesting in the form of violence including terrorism. To proactively counter ideological extremism that leads to terrorism, it is necessary to build community support to detect signs of radicalization. Similarly, to proactively counter terrorism, it is necessary to orient the community to detect signs of a terrorist attack. These signs make up indicators such as propaganda, recruitment, funding, procurement, safe house, transport, communication, travel, training, multiple identities, surveillance, reconnaissance, rehearsal, and attack. These signs and indicators are best detected by members of the community and frontline officers. However, threat detection is contingent on orientation to the threat, focused alertness and vigilance. The government sharing pre-attack indicators selectively with trusted community partners will increase the probability of detecting a terrorist attack.

Traditional community engagement is aimed at preventing crime and terrorism. The most current view is that the government-community partnership should move a step further and promote moderation, toleration and coexistence. In a society, where resilience is built, all communities will remain united in the event of a terrorist attack. In the face of adversity, they will help each other and each other's communities to recover rapidly and return to normalcy.

\section{Origins of Community Engagement}

Traditionally, governments focused on eliminating, preventing and controlling crime. With the rise of crime, community-oriented policing emerged in the 1960s. Going back to the period immediately after World War II, Allied Governments engaged in de-Nazification programs to mainstream German thinking. Governments have always realized the value of 
and relied on working with the community to counter extremism ideologies. ${ }^{10}$ As terrorism was not a significant threat until 9-11, governments did not rely on community support to fight terrorism. In the post 9-11 environment, to counter the threat of group and homegrown terrorism especially self-radicalization, community engagement programs emerged globally. Community engagement strategies for countering extremism in many countries drew significantly from police-community relations especially mobilizing the community against crime. While the Muslim Contact Unit (MCU) at New Scotland Yard formed the inspiration for most programs in the West, Singapore's Community Engagement Program (CEP) was an actor with capability of influences as much as a trend setter. Although NYPD released its own report, it failed to engage the Muslim community. ${ }^{11}$ While the NYPD Intelligence Division and Counter Terrorism Bureau were well funded, its Community Affairs Division was poorly funded and poorly led. ${ }^{12}$

Public awareness was raised formally and informally to fight crime since the late 1960s and terrorism during the last decade. The origins of engaging the community to prevent crime in many countries came from Japan. To remain in direct contact with the civilians, the Japanese created the systems where community police officers maintained an active presence. Brazil, Fiji, Mongolia, Singapore and other countries adopted Japan's Koban and Chuzaisho system developed in the second half of the 1800s. To quote Jarmal Singh from the Singapore Police Force: "The basic premise of community policing is that the police and the members of the public should work together to eliminate, suppress and prevent crime in society. This is an extension of the realisation that crime is a community problem created by societal issues and failures, and not just a police issue or an indication of its effectiveness. Police effectiveness and public order cannot be greatly enhanced unless the community can be persuaded to do more for itself." 13 Community policing sought to raise awareness by informing and educating the public "about crime, its causes and effects within the society." ${ }^{14}$ While stimulating the society to self-police, community engagement actively sought to mobilize the various sections of the community - public organizations, private firms, governmental agencies and the general population. ${ }^{15}$ Fighting narcotics also involved the community.

\section{Countering Extremism and Building Social Resilience}

Both to the community and to government, experts need to explain why community engagement is central to counter extremism. To raise public awareness, they need to explain the impact of both terrorism and extremist thinking. Working with government and other partners, law enforcement authorities who understand the threat should play a direct role in formal and informal education. To build social resilience, the public should be informed about the gradual process of radicalization. When the threat became apparent, law enforcement

\footnotetext{
${ }^{10}$ Cooper, Kristi: “Amrokraten, Bemokraten and Cemokraten": A Case Study of Denazification and Leadership in World War II, 1944 - 1949”, Presentation at the International Centre for Political Violence and Terrorism Research, Singapore, 26 September 2011.

11 Silber, Mitchell D. and Bhatt, Arvin: "Radicalization in the West: The Homegrown Threat", Senior Intelligence Analysts, NYPD Intelligence Division, NYPD, (2008), at http://sethgodin.typepad.com/seths blog/files/NYPD_Report-Radicalization_in the West.pdf.

${ }^{12}$ Interviews with NYPD leaders, 2008.

13 Singh, Jarmal: "Community Policing in the Context of Singapore", $112^{\text {th }}$ International Training Course, Visiting Experts' Papers (30August - 18 November 1999), Resource Material Series, no. 56, UNAFEI, Fuchu, Tokyo, Japan (December 2000).

${ }^{14}$ Ibid.

${ }^{15}$ Ibid.
} 
authorities such as the New York Police Department and intelligence services like the Internal Security Department in Singapore began to reach out to the public. To build resilience within the vulnerable segments of the community, they reached out to the very same community segments targeted by the terrorists. By becoming aware, community members resisted the radical message. They did not get carried away and easily fall victim to the terrorist message couched in carefully selected ethnic or religious language.

Dependent on the ideological threat, law enforcement officers, academics and scholars, including religious personalities such as clerics knowledgeable about terrorism reached out to the public. They sought to explain the difference between extremist ideology versus mainstream ideology. As the terrorists seeking to exploit religion sought to trap youth under the guise of being men of religion, it was necessary to draw a line between political and religious ideology and hate filled extremist narrative. Otherwise a youth listening to a terrorist ideologue masquerading as a holy man can get carried away. Such an investment enabled the general public especially the vulnerable youth population to establish the difference between what is deviant and heretical thinking versus mainstream discourse.

It is not only religion that was exploited by terrorist ideologues but also ethnicity. Terrorist ideologues seeking to exploit ethnicity to recruit or raise funds could harness ethnic sentiments. In such cases, where ethno-political ideology was the driver, it was necessary to promote values of moderation, toleration and coexistence. Leaders and elite of ethnic communities should work within the community and with other communities to resolve differences that are likely to emerge from time to time. In the spirit of amicable resolution of disputes and building bridges of friendship through reconciliation, harmony centers can be created and managed at local, metropolitan, provincial and federal level.

\section{The Wav Forward}

To make the public aware, it is necessary to formally and informally educate them through multiple platforms. They include the mass media by educating media personnel, revamping the school curricula and training the teachers, delivering talks at workplaces by trained trade unionists, youth organizations by trained youth leaders, grassroots organizations by grassroots leaders, and other venues. As vote driven politicians both in the east and the west are most susceptible to playing the ethnic and religious card, it is important for politicians to be made aware and held accountable to a higher degree.

Members of the communities will gradually understand that they too must protect their community by playing an active role. They will begin to report suspicious activities to the authorities, either face-to-face or by letter or phone. Anyone that sought to divide communities and disrupt harmony by disseminating hate-filled propaganda, recruit, raise fund, procure supplies, organize safe houses, or train should be brought to the attention of the authorities.

Some members of the community go out of their way to organize meetings with members of other communities to build greater understanding. Such meetings reduce and remove suspicion of each other and pave the way for permanent friendships. In the event of a terrorist attack, the larger society will not perceive the community at risk as a whole responsible for the attack but blame the few misguided individuals. While ethnic and religious sympathies will remain, those enlightened will be driven to protect and take care of the 
community at risk. The terrorist intent is not merely to attack and destroy a target but trigger ethnic and religious riots. The members of the society should be made aware of terrorist intent of creating disharmony by prompting one community to clash with another community. If members of the community are not educated, the resultant rioting would gravely hurt the social fabric of any society. The community members aware of terrorist attempts to disrupt ethnic and religious harmony can prevent such incidents. Community engagement initiatives aimed at forging national unity can instill a sense of belonging to country and society 